ISSN: 2362-1303 (Paper) | eISSN: 2362-1311(Online)

\title{
Impacts of Melamchi Water Supply Project in Socio-Economic Development of Sindhupalchowak District of Nepal
}

\author{
Dhundi Raj Dahal $^{1}$ \& Prof. Dr. Tatwa P. Timsina ${ }^{2}$ \\ ${ }^{1} \mathrm{PhD}$ Scholar, Mewar University, Rajasthan, India \\ ${ }^{2}$ Professor, Tribhuvan University, Kathmandu, Nepal
}

Corresponding Author

Dhundi Raj Dahal

dhundi_raj2000@yahoo.com

\begin{abstract}
The Melamchi Water Supply Project (MWSP) is considered to have been the most viable long-term alternative to ease the chronic water shortage situation within the Kathmandu Valley. The project has launched the separate project 'Social Upliftment Project' to improve the quality of life of community people. Besides that the project has divided its support field as buffer zone, health, education, income generation and rural electrification etc. to make the program more effective. So, the study aim is to explore the impact of Melamchi Water Supply Project in socio-economic status of local people of study areas. The study was conducted among the 8 VDCs of Sindhupalchowak district. Total, 404 respondents were selected randomly. The study found that MWSP had contributed in the field of agriculture, improving economic status of community people, education, infrastructure development and off-seasonal vegetable farming for income generating activities. There was a significant difference between the respondents of different VDCs regarding the contribution of MWSP. The Social Upliftment Program of MWSP should be continued and needed to extend in other hard-to-reach areas of district.
\end{abstract}

\section{KEYWORDS}

Impacts, Melamchi Water Supply Project, Socio-Economic Development

\section{INTRODUCTION}

The Melamchi Water Supply Project (MWSP) is considered to be the most viable longterm alternative to ease the chronic water shortage situation within the Kathmandu Valley. The Project is designed to divert about 170 MLD of fresh water to Kathmandu Valley from the Melamchi River in Sindhupalchowk district. Augmenting this supply by adding about a further 170 MLD each from the Yangri and Larke rivers, which lie in the upstream proximity of 
ISSN: 2362-1303 (Paper) | eISSN: 2362-1311(Online)

JOURNAL OF ADVANCED ACADEMIC RESEARCH (JAAR)

July 2015

Melamchi are also being investigated as future supply sources. Ministry of Urban Development (MOUD) is the executing agency for the Project and an autonomous Melamchi Water Supply Development Board, formulated for the Project implementation, is the implementing agency.

The Board, as an independent project implementing body has come a long way to collect the necessary funds to implement the project since 1998. The major donor of the project, Asian Development Bank (ADB) approved a Loan 1820-NEP (SF) on 21st December, 2000 and it was effective from 28th November, 2001. After six years of project implementation, Government of Nepal and the project's funding partners, felt necessity to change the scopes of project implementation arrangement by splitting the MWSP into the following two distinct sub-projects in 2007:

(i) Melamchi River Water Diversion Subproject (Sub-Project -1); covering the activities of (Land Acquisition \& Infrastructure Development Program, Social Uplift program, Environmental Management Program, Water Treatment Plant and Melamchi Water Diversion Scheme.

(ii) Kathmandu Valley Water Supply and Sanitation Subproject (Subproject -2) ;comprising water distribution activities in Kathmandu Valley. EMP implementation requirements as per EIA and EMP of MWSP, 2000 and 2001 have been covered both of these sub-projects.

The MWSP originally comprised four parts:

i) Infrastructure development;

ii) Social and environmental support;

iii) Institutional reforms; and

iv) Project implementation support. (Melamchi Water Supply Project, 2015)

The objective of the Melamchi Diversion Scheme is to transfer raw water from the Melamchi River to the water treatment facility in Sundarijal in the Kathmandu valley through a $27 \mathrm{~km}$ long tunnel. The overall object of the project is to provide an efficient and safe potable water supply, improvement health conditions and economic development in the Kathmandu valley. The Social Uplift Programme (SUP) aims to ensure that the project affected people of the Melamchi Valley, Sindhupalchok district is also benefitted from the project and that sustainable development in the natural resource management, health, education, income generation and community development and rural electrification can create significant improvements in the quality of life in the Melamchi Valley (Pokharel, 26-30 June, 2006, p. 1). According to the Melamchi Water Supply Project report of 2013, MWSP has conducted the social support activities in 14 VDCs (Melamchi, Duwachaur, Bashwari, Talamarang, Phatkashila, Helambu, Ichowak, Mahankal, Kiual, Palchok, Bhotechaur, Thakani, Sindhukot and Haibung). MWSP has conducted the education, Health, Rural electrification, Income generating \& social development activities. As well as, the project had developed the Environment Management Plan also to reduce the negative impact in environment (Melamchi Drinking Water Development Committee, April 2014). 
ISSN: 2362-1303 (Paper) | eISSN: 2362-1311(Online)

JOURNAL OF ADVANCED ACADEMIC RESEARCH (JAAR)

July 2015

The background information of project and previous study gives the clear picture that MWSP has significant contribution to uplift the socio-economic status of local community. The project has launched the separate project 'Social Upliftment Project' to improve the quality of life. Besides that the project has divided its support field as buffer zone, health, education, income generation and rural electrification etc. to make the program more effective. So, regarding these effort of MWSP, the study is going to explore the impact of Melamchi Water Supply Project in socio-economic status of local people of study areas.

\section{METHOD}

The study was based on the descriptive as well as exploratory research design which aim was to describe the socio-economic impact of Melamchi Water Supply Project (MWSP) in Sindhupalchowak district of Nepal and its association between VDCs. The study had selected the 8 most affected VDC by MWSP. The respondents were selected using the simple random sampling techniques from the selected VDCs. Sample was distributed on the basis of size of total universe. The pure quantitative data was collected by using the structured survey. Total 404 respondents were selected for study. Frequency table and Chi-Square test was used to analyze the data and data are presented in the tabular form.

\section{RESULT \& DISCUSSION}

The study had covered the 8 Village Development Committees (VDCs) of Sindhupalchowak district of Nepal. The data showed that in total, $20.8 \%$ respondents were participated from the Melamchi followed by $15.6 \%$ respondents were from the Helambu, $13.4 \%$ were from the Ichok, $12.1 \%$ were from Kiula, $11.1 \%$ were from Mahankal, $10.6 \%$ were from the Duwachaur, 9.4\% were from Talamaranga and $6.9 \%$ were from the Palchok. In total $55.7 \%$ male followed by $44.3 \%$ female had participated in the study. In total, $44.3 \%$ respondents were Janjati (ethnic groups) followed by $27.7 \%$ were Chhetri, $18.8 \%$ were Brahmin, $4.2 \%$ were Dalit (who are called untouchable caste) and 5\% were other castes. The other caste covers Jaisi, Madhesi, and Muslim. in total 28\% participants were illiterate whereas $30.4 \%$ respondents had primary level education followed by $12.9 \%$ had lower secondary level, $12.1 \%$ had secondary level, $7.9 \%$ had intermediate level, $6.2 \%$ had bachelor level and only $2.5 \%$ had master and above level education.

The main objective of this study was to explore the socio-economic impact of Melamchi water supply project. The impact was measured especially on the physically components of the study areas: water supply for agriculture, economic status of local people, educational development, road construction, off-seasonal vegetable production, forest management etc.

1. Contribution of Melamchi Water Supply Project (MWSP) in managing the water supply for agriculture

Humans depend on water in many ways, well beyond the few liters needed daily for drinking. Water is also essential for the production of food. Various forms of agriculture, 
ISSN: 2362-1303 (Paper) | eISSN: 2362-1311(Online)

JOURNAL OF ADVANCED ACADEMIC RESEARCH (JAAR)

July 2015

practiced on about half of Earth's land surface, provide the vast majority of food that over 6 billion people eat. Agriculture also provides much of the fiber for cotton, wool, and linen clothing. Because agricultural crops are so dependent on water, purposely adding water, beyond what naturally falls as rain is widely practiced to increase agricultural production. This critical practice is known as irrigation. Irrigation is an ancient practice that originated along the Tigris and Euphrates Rivers in what is now Iraq, and spread in ancient times to the desert valley of the Nile River in Egypt, the Indus River in Pakistan, and all the way to China. Native Americans also practiced irrigation long ago, especially in the areas now called Mexico and the south western United States. It is estimated that $40 \%$ of all crops grown in the world today are grown using irrigation. In the twentieth century, the practice of irrigation was greatly increased to provide food for the world's growing population. Globally, irrigation now accounts for $69 \%$ of the 3,240 cubic kilometers (772 cubic miles) of water withdrawn for human use, and $87 \%$ of all water consumed. Asia, with the majority of Earth's population, remains the world's most irrigated region. The three most populous countries - China, India, and the United States - are also the leading countries in irrigated area and in water used in irrigation, as shown in the table. Pakistan and especially Egypt remain the country's most dependent on irrigation, although other countries of dry south western and central Asia (e.g., Saudi Arabia, Iran, Iraq, and Uzbekistan) greatly depend on irrigation for their food and fiber supplies (Water Encyclopedia, 2015).

The study had collected the data related to the contribution of Melamchi Water Supply Project in managing the water supply for agriculture in the surrounding communities of project. The data presented in table no. 1 showed that in total $25.2 \%$ agree followed by $5.2 \%$ strongly agree that MWSP had contributed in managing the water supply for agriculture whereas $34.4 \%$ strongly disagree followed by $5.2 \%$ disagree on the contribution of MWSP in water supply for agriculture. As the reported data, more people were not accepting that the MWSP had significant contribution in the field of agricultural development.

Table 1: contribution in managing the water supply for agriculture

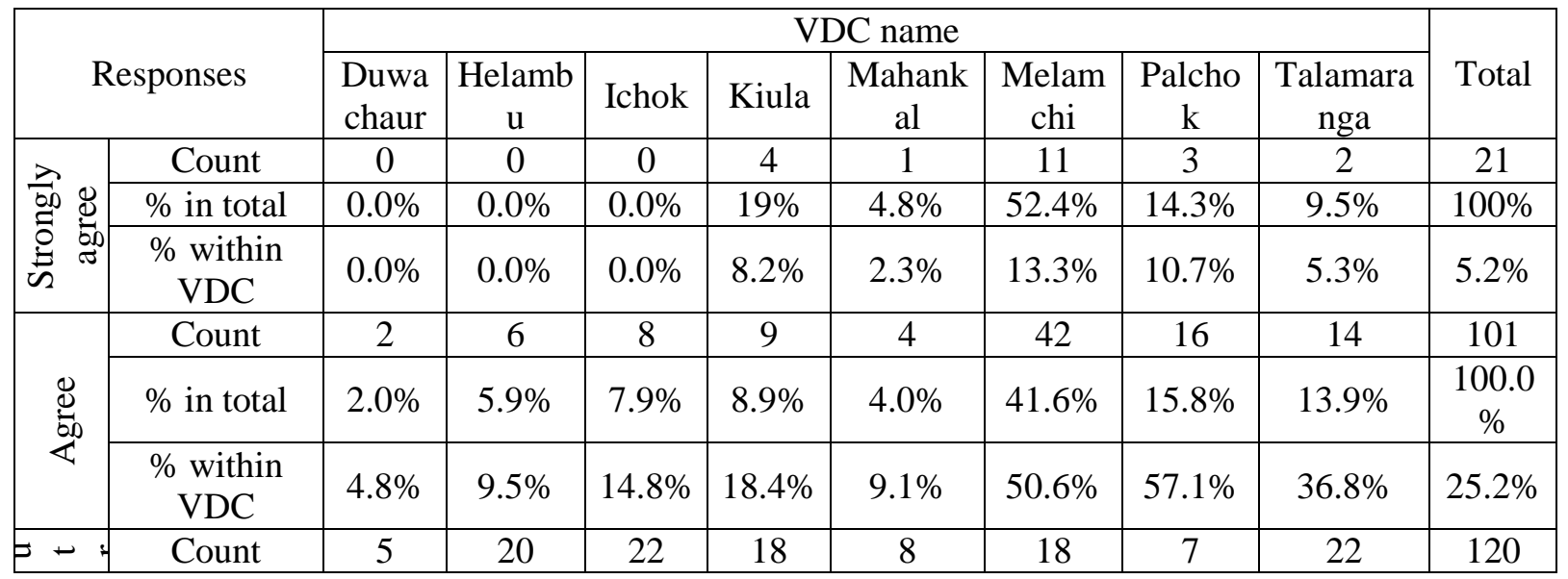

Vol. 2. No. II

www.phdcentre.edu.np 
ISSN: 2362-1303 (Paper) | eISSN: 2362-1311(Online)

JOURNAL OF ADVANCED ACADEMIC RESEARCH (JAAR)

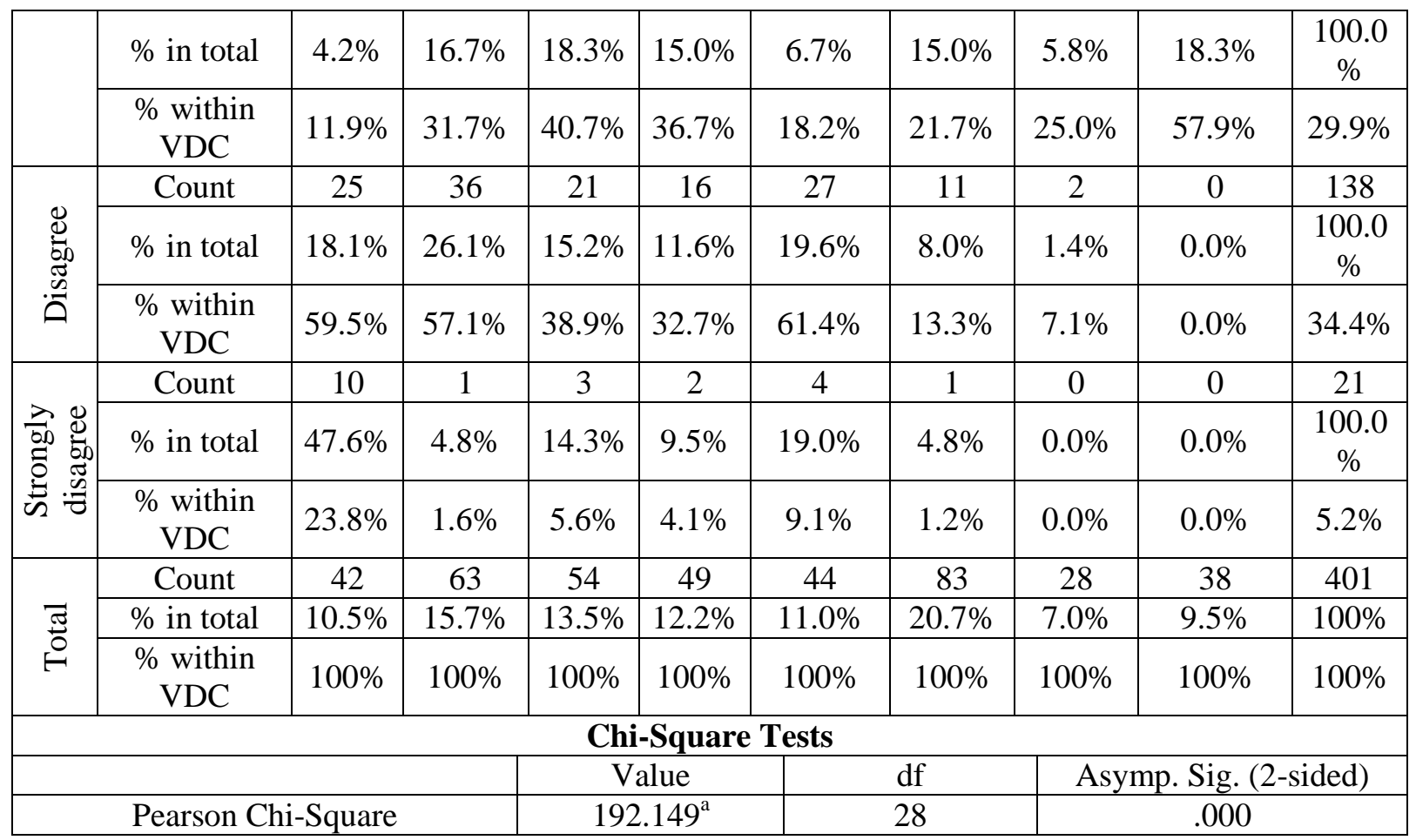

Source: Field Survey, 2014

The response of VDCs wise data shows that Duwachaur (2), Helambu (6), Ichok (8), Kiula (13) and Mahankal (5) were found very few respondents agreeing the contribution of MWSP on water supply for agriculture. It can be assumed that there was unequal distribution of water supply for agriculture. The statistical analysis of Chi-square test showed that there was significant association $(\mathrm{P}=.000)$ between the types of VDCs and MWSP contribution on water supply for agriculture.

The agricultural census report of 2011 of Central Bureau of Statistic of Nepal, 53\% agricultural land has irrigation facility. The sources of irrigation are: $48 \%$ sources are river or lake, $30 \%$ are Tubel or boring, $16 \%$ are Reserve-ware or pond, $4 \%$ are others and $2 \%$ are mixed (Central Bureau of Statistics, 2011). Water plays a fundamental role in farming and anybody planning to set out as a farmer must consider the availability of a reliable water source near the place where he or she intends to put up the farm. Water is very important for both livestock and for plants. It forms a large part of all plant tissues as well as being an essential component of all animal body cells (Ssali, 2015). Water is crucial for socio-economic development and healthy ecosystems. With the actual population growth and in view of future water scarcity, development calls for improved sectorial allocation of groundwater and surface water for domestic, agricultural and industrial use (Rajaona, Sutterer, \& Asch, 2012, p. 376).

2. Contribution of Melamchi Water Supply Project to increase the economic status of local people

Over the past fifteen years, real per capita consumption has grown by an average of $3.5 \%$ per year and the Human Development Index has improved at a rate of $2.6 \%$ per year Vol. 2. No. II 
ISSN: 2362-1303 (Paper) | eISSN: 2362-1311(Online)

JOURNAL OF ADVANCED ACADEMIC RESEARCH (JAAR)

July 2015

through 1980-2010. In terms of poverty, some $25 \%$ of the Nepali population found themselves below the poverty line in 2010-11 a significant drop of about 30 percentage points from 199596. Using the international poverty line of Purchasing Power Parity (PPP) US $\$ 1.25$ per capita per day, the proportion of poor in the population halved to $24.8 \%$ and Nepal 'overtook' both Bangladesh and India in terms of poverty prevalence (The World Bank Group, 2014). The Gross Domestic Product per capita in Nepal was last recorded at 426.48 US dollars in 2014. The GDP per Capita in Nepal is equivalent to 3 percent of the world's average. GDP per capita in Nepal averaged 246.98 USD from 1960 until 2014, reaching an all-time high of 426.48 USD in 2014 and a record low of 177.77 USD in 1960. GDP per capita in Nepal is reported by the World Bank (TRADING ECONOMICS, 2015).

Melamchi water supply project was also working to uplift the economic status of community people by doing the different types of income generating activities. But proper implementation of activities was more challenging. A study conducted by Binod Pokharel on effects of political parties in the implementation of Income Generation and Community Development Programme (IGCD) conducted under the Melamchi Water Supply Project and charts how, different political parties and local government body manipulate the given model of community development for their political interest. IGCD was designed to achieve sustainability by working within existing local government structures and strengthening these structures by using the participatory and capacity building approaches of the Local Governance Programme. However, in course of implementation several disagreements, constraints and debates emerged among the political parties and local government officials due to manipulation of project modality by the political parties as well as the local government officials in accordance with their dynamic personal political interests. The study found that the political parties at the local level manipulated the project modality for the political gain and to secure the position in the coming election (Pokharel, 26-30 June, 2006).

Table 2: Contribution to increase the economic status of local people

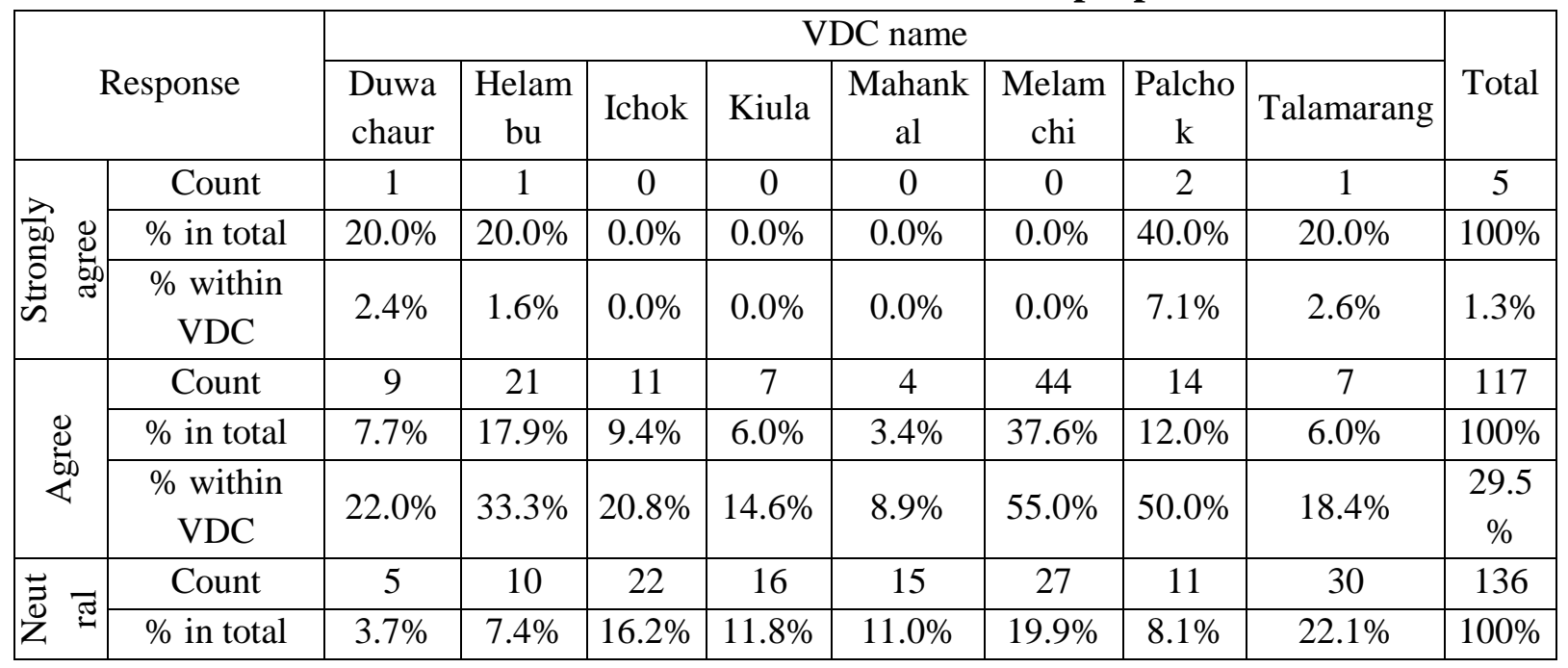

Vol. 2. No. II

www.phdcentre.edu.np 
ISSN: 2362-1303 (Paper) | eISSN: 2362-1311(Online)

JOURNAL OF ADVANCED ACADEMIC RESEARCH (JAAR) July 2015

\begin{tabular}{|c|c|c|c|c|c|c|c|c|c|c|}
\hline & $\begin{array}{c}\% \text { within } \\
\text { VDC }\end{array}$ & $12.2 \%$ & $15.9 \%$ & $41.5 \%$ & $33.3 \%$ & $33.3 \%$ & $33.8 \%$ & $39.3 \%$ & $78.9 \%$ & $\begin{array}{c}34.3 \\
\%\end{array}$ \\
\hline \multirow{3}{*}{ 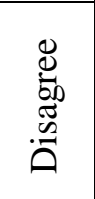 } & Count & 22 & 30 & 15 & 21 & 8 & 7 & 1 & 0 & 104 \\
\hline & $\%$ in total & $21.2 \%$ & $28.8 \%$ & $14.4 \%$ & $20.2 \%$ & $7.7 \%$ & $6.7 \%$ & $1.0 \%$ & $0.0 \%$ & $100 \%$ \\
\hline & $\begin{array}{c}\% \text { within } \\
\text { VDC }\end{array}$ & $53.7 \%$ & $47.6 \%$ & $28.3 \%$ & $43.8 \%$ & $17.8 \%$ & $8.8 \%$ & $3.6 \%$ & $0.0 \%$ & $\begin{array}{c}26.3 \\
\%\end{array}$ \\
\hline \multirow{3}{*}{ 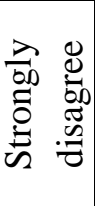 } & Count & 4 & 1 & 5 & 4 & 18 & 2 & 0 & 0 & 34 \\
\hline & $\%$ in total & $11.8 \%$ & $2.9 \%$ & $14.7 \%$ & $11.8 \%$ & $52.9 \%$ & $5.9 \%$ & $0.0 \%$ & $0.0 \%$ & $100 \%$ \\
\hline & $\begin{array}{c}\% \text { within } \\
\text { VDC }\end{array}$ & $9.8 \%$ & $1.6 \%$ & $9.4 \%$ & $8.3 \%$ & $40.0 \%$ & $2.5 \%$ & $0.0 \%$ & $0.0 \%$ & $8.6 \%$ \\
\hline \multirow{3}{*}{ 营 } & Count & 41 & 63 & 53 & 48 & 45 & 80 & 28 & 38 & 396 \\
\hline & $\%$ in total & $10.4 \%$ & $15.9 \%$ & $13.4 \%$ & $12.1 \%$ & $11.4 \%$ & $20.2 \%$ & $7.1 \%$ & $9.6 \%$ & $100 \%$ \\
\hline & $\begin{array}{c}\% \text { within } \\
\text { VDC }\end{array}$ & $100.0 \%$ & $100 \%$ & $100 \%$ & $100 \%$ & $100.0 \%$ & $100.0 \%$ & $100 \%$ & $100.0 \%$ & $100 \%$ \\
\hline \multicolumn{11}{|c|}{ Chi-Square Tests } \\
\hline & & & & \multicolumn{2}{|c|}{ Value } & & $\mathrm{df}$ & \multicolumn{3}{|c|}{ Asymp. Sig. (2-sided) } \\
\hline \multicolumn{4}{|c|}{ Pearson Chi-Square } & \multicolumn{2}{|c|}{$201.396^{\mathrm{a}}$} & & 28 & \multicolumn{3}{|c|}{.000} \\
\hline
\end{tabular}

Source: Field Survey, 2014

The study had asked the community people who were living near to the Melamchi water supply project about the contribution of project to increase the economic status of local people. As the secondary information found from the project shows that project had done work on the field of income generating activities; production of off-seasonal vegetables. So, the data was collected in the same issue. The data of table no. 2 shows that in total only $1.3 \%$ respondents were strongly agree followed by $29.5 \%$ agreed that Melamchi water supply project had contributed to increase the economic status of local people whereas $26.3 \%$ were disagree followed $8.6 \%$ strongly disagree in the contribution of MWSP to increase the economic status of local people. In total, around $31 \%$ people agreed whereas around $35 \%$ respondents were disagreed and remaining were in neutral. In this data, it can be said that there was no significant impact of MWSP to increase the level of economic status of local people.

District wise, 4 respondents of Mahankal, 7 of Kiula, 8 of Talamarang, 10 of Duwachaur and 11 respondents of Ichok VDCs agreed that MWSP had contributed to increase the economic status of local people of these particular VDCs. Within VDCs, 55\% of Melamchi and 50\% of Palchok agreed that MWSP had contributed in economic status of local people. Data showed that contribution was varied from VDC to VDC.

There was significant association $(\mathrm{P}=.000)$ between the types of VDCs and response on contribution of MWSP to increase the economic status of local people.

\section{Contribution of Melamchi Water Supply Project in educational development of local people}

Education is the main back bone of development. So, Governmental and nongovernmental organization are contributing in the field of education. Regarding this issue, the Vol. 2. No. II

www.phdcentre.edu.np 
ISSN: 2362-1303 (Paper) | eISSN: 2362-1311(Online)

JOURNAL OF ADVANCED ACADEMIC RESEARCH (JAAR)

study had asked the respondents about the contribution of MWSP in educational development in local level. The data of table no. 3 reported that in total $7.8 \%$ strongly agreed followed $53.5 \%$ agreed that MWSP had contributed in educational development of local people. From the discussion with local people, it was informed that MWSP had supported to build the school building.

The data of VDC wise, $66.6 \%$ respondents of Melamchi agreed that MWSP had supported in educational development of that VDC followed by $30 \%$ respondents of Palchok, $27 \%$ respondents of Duwachaur, $25.2 \%$ of Helambu, $21.8 \%$ Kiula, $17.5 \%$ respondents of Talamarang $11 \%$ of Ichok and only $1.1 \%$ of Mahankal. The data reported that Melamchi VDC was significantly highly benefited than the other VDC. It could be assumed that MWSP is located in the Melamchi VDC so project had given priority to development of Melamchi VDC.

Table 3: Contribution MWSP in educational development of local people

\begin{tabular}{|c|c|c|c|c|c|c|c|c|c|c|}
\hline \multirow{2}{*}{\multicolumn{2}{|c|}{ Res }} & \multicolumn{8}{|c|}{ VDC name } & \multirow[b]{2}{*}{ Total } \\
\hline & & \multirow{2}{*}{$\begin{array}{c}\begin{array}{c}\text { Duwa } \\
\text { chaur }\end{array} \\
3\end{array}$} & \multirow{2}{*}{$\begin{array}{c}\text { Helamb } \\
\mathrm{u} \\
1\end{array}$} & \multirow{2}{*}{$\begin{array}{c}\text { Ichok } \\
1\end{array}$} & \multirow{2}{*}{$\frac{\text { Kiula }}{3}$} & \multirow{2}{*}{$\begin{array}{c}\text { Mahank } \\
\text { al } \\
0\end{array}$} & \multirow{2}{*}{$\begin{array}{c}\text { Melamch } \\
\text { i } \\
12\end{array}$} & \multirow{2}{*}{$\begin{array}{c}\text { Palcho } \\
\mathrm{k} \\
5\end{array}$} & \multirow{2}{*}{ 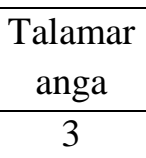 } & \\
\hline & Count & & & & & & & & & 28 \\
\hline 00 & $\%$ in total & $10.7 \%$ & $3.6 \%$ & $3.6 \%$ & $10.7 \%$ & $0.0 \%$ & $42.9 \%$ & $17.9 \%$ & $10.7 \%$ & $100.0 \%$ \\
\hline 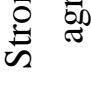 & $\begin{array}{c}\% \text { within } \\
\text { VDC }\end{array}$ & $7.5 \%$ & $1.6 \%$ & $2.3 \%$ & $7.0 \%$ & $0.0 \%$ & $17.1 \%$ & $17.9 \%$ & $9.1 \%$ & $7.9 \%$ \\
\hline \multirow{3}{*}{ 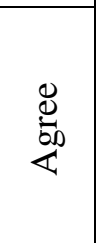 } & Count & 31 & 41 & 14 & 21 & 2 & 45 & 23 & 13 & 190 \\
\hline & $\%$ in total & $16.3 \%$ & $21.6 \%$ & $7.4 \%$ & $11.1 \%$ & $1.1 \%$ & $23.7 \%$ & $12.1 \%$ & $6.8 \%$ & $100.0 \%$ \\
\hline & $\begin{array}{c}\% \text { within } \\
\text { VDC }\end{array}$ & $77.5 \%$ & $67.2 \%$ & $31.8 \%$ & $48.8 \%$ & $5.6 \%$ & $64.3 \%$ & $82.1 \%$ & $39.4 \%$ & $53.5 \%$ \\
\hline \multirow{3}{*}{$\begin{array}{l}\text { 芯 } \\
\text { 芯 } \\
Z\end{array}$} & Count & 1 & 7 & 16 & 11 & 10 & 10 & 0 & 17 & 72 \\
\hline & $\%$ in total & $1.4 \%$ & $9.7 \%$ & $22.2 \%$ & $15.3 \%$ & $13.9 \%$ & $13.9 \%$ & $0.0 \%$ & $23.6 \%$ & $100.0 \%$ \\
\hline & $\begin{array}{c}\% \text { within } \\
\text { VDC }\end{array}$ & $2.5 \%$ & $11.5 \%$ & $36.4 \%$ & $25.6 \%$ & $27.8 \%$ & $14.3 \%$ & $0.0 \%$ & $51.5 \%$ & $20.3 \%$ \\
\hline \multirow{3}{*}{ 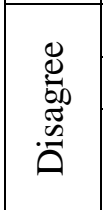 } & Count & 4 & 12 & 10 & 6 & 3 & 2 & 0 & 0 & 37 \\
\hline & $\%$ in total & $10.8 \%$ & $32.4 \%$ & $27.0 \%$ & $16.2 \%$ & $8.1 \%$ & $5.4 \%$ & $0.0 \%$ & $0.0 \%$ & $100.0 \%$ \\
\hline & $\begin{array}{c}\% \text { within } \\
\text { VDC }\end{array}$ & $10.0 \%$ & $19.7 \%$ & $22.7 \%$ & $14.0 \%$ & $8.3 \%$ & $2.9 \%$ & $0.0 \%$ & $0.0 \%$ & $10.4 \%$ \\
\hline \multirow{3}{*}{ 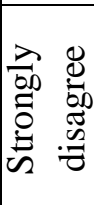 } & Count & 1 & 0 & 3 & 2 & 21 & 1 & 0 & 0 & 28 \\
\hline & $\%$ in total & $3.6 \%$ & $0.0 \%$ & $10.7 \%$ & $7.1 \%$ & $75.0 \%$ & $3.6 \%$ & $0.0 \%$ & $0.0 \%$ & $100.0 \%$ \\
\hline & $\begin{array}{c}\% \text { within } \\
\text { VDC }\end{array}$ & $2.5 \%$ & $0.0 \%$ & $6.8 \%$ & $4.7 \%$ & $58.3 \%$ & $1.4 \%$ & $0.0 \%$ & $0.0 \%$ & $7.9 \%$ \\
\hline \multirow{3}{*}{$\stackrel{\pi}{0}$} & Count & 40 & 61 & 44 & 43 & 36 & 70 & 28 & 33 & 355 \\
\hline & $\%$ in total & $11.3 \%$ & $17.2 \%$ & $12.4 \%$ & $12.1 \%$ & $10.1 \%$ & $19.7 \%$ & $7.9 \%$ & $9.3 \%$ & $100.0 \%$ \\
\hline & $\begin{array}{c}\% \text { within } \\
\text { VDC }\end{array}$ & $100 \%$ & $100.0 \%$ & $100 \%$ & $100 \%$ & $100.0 \%$ & $100.0 \%$ & $100.0 \%$ & $100.0 \%$ & $100.0 \%$ \\
\hline
\end{tabular}

Vol. 2. No. II

www.phdcentre.edu.np 
ISSN: 2362-1303 (Paper) | eISSN: 2362-1311(Online)

JOURNAL OF ADVANCED ACADEMIC RESEARCH (JAAR)

July 2015

\begin{tabular}{|c|c|c|c|}
\hline \multicolumn{4}{|c|}{ Chi-Square Tests } \\
\hline & Value & Df & Asymp. Sig. (2-sided) \\
\hline Pearson Chi-Square & $244.272^{\mathrm{a}}$ & 28 & .000 \\
\hline
\end{tabular}

Source: Field Survey, 2014

The Pearson Chi-square test gave that there was significant association $(\mathrm{P}=.000)$ between the VDCs and contribution of MWSP in educational development at the $95 \%$ confidence interval.

Melamchi Water Supply Project was implementing the Social Upliftment Program in the Project affected areas. The main aim of the Social Upliftment Program (SUP) is to engage local participation in the mitigation of direct and indirect project impacts and to create a base for long-term development in project-affected VDCs, to improve quality of life. In order to make this program more effective and result oriented the project has divided it support field as buffer zone, health, education, income generation and rural electrification etc. the aim of Education program was to assist in the development and upgrading of Melamchi Valley education through support to schools, including the building or upgrading of physical facilities, implementation of school sanitation programs, training of teachers, provision of grants and scholarships, and implementation of adult literacy programs including supply of basic education materials (Melamchi Water Supply Project, 2015).

\section{Contribution of Melamchi Water Supply Project in road construction}

Social development is measured by the infrastructure development of particular society. Road access is the primary need of people to move from one place to another place. It was informed that MWSP had contributed in the construction of road. The information was collected from the community people also. The table no. 4 explained that in total $61.4 \%$ respondent agreed followed by $15.3 \%$ strongly agreed that MWSP had contributed in road construction. Comparative data of VDCs showed that $96.5 \%$ of Palchok followed by $93.6 \%$ respondents of Helambu, $89.2 \%$ of Melamchi, $83.7 \%$ of Duwachaur, $77.7 \%$ of Mahankal, $77.6 \%$ of Kiul, $47.3 \%$ of Talamarang and $39.2 \%$ respondents of Ichok accepted the contribution of MWSP in road construction in these VDCs.

Table 4: Contribution of Melamchi Water Supply Project in road construction

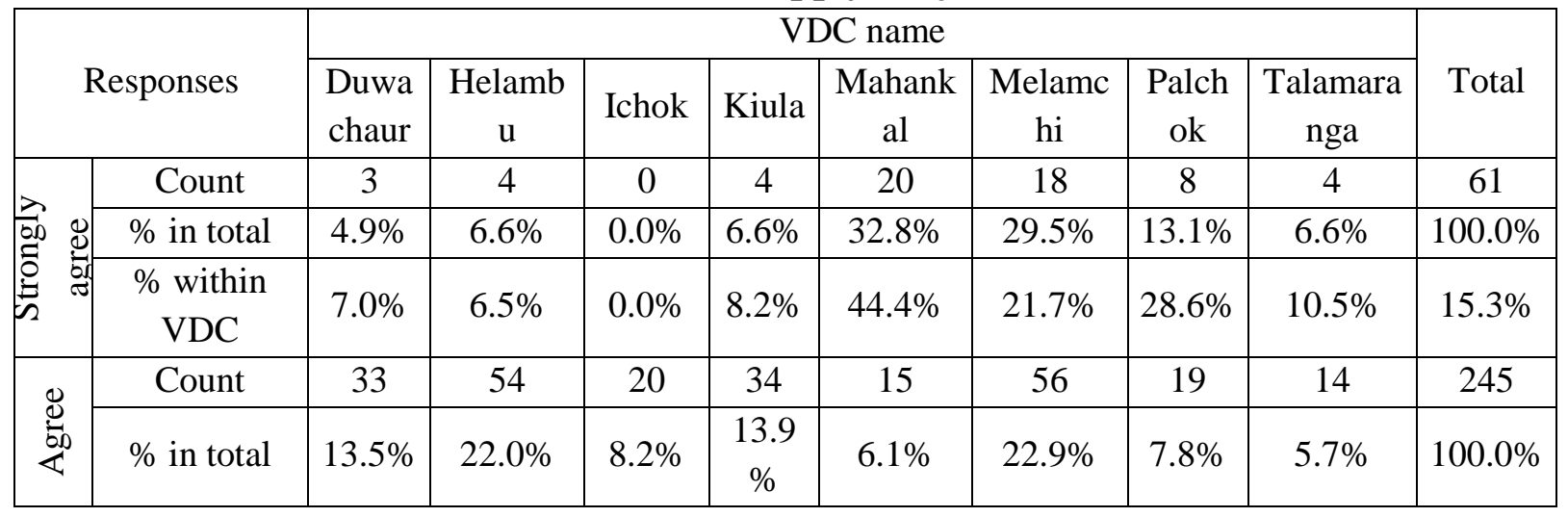

Vol. 2. No. II

www.phdcentre.edu.np 
ISSN: 2362-1303 (Paper) | eISSN: 2362-1311(Online)

JOURNAL OF ADVANCED ACADEMIC RESEARCH (JAAR)

July 2015

\begin{tabular}{|c|c|c|c|c|c|c|c|c|c|c|}
\hline & $\begin{array}{c}\% \text { within } \\
\text { VDC }\end{array}$ & $76.7 \%$ & $87.1 \%$ & $39.2 \%$ & $\begin{array}{c}69.4 \\
\%\end{array}$ & $33.3 \%$ & $67.5 \%$ & $67.9 \%$ & $36.8 \%$ & $61.4 \%$ \\
\hline \multirow{3}{*}{ 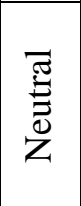 } & Count & 0 & 4 & 21 & 4 & 0 & 7 & 1 & 20 & 57 \\
\hline & $\%$ in total & $0.0 \%$ & $7.0 \%$ & $36.8 \%$ & $7.0 \%$ & $0.0 \%$ & $12.3 \%$ & $1.8 \%$ & $35.1 \%$ & $100.0 \%$ \\
\hline & $\begin{array}{l}\text { \% within } \\
\text { VDC }\end{array}$ & $0.0 \%$ & $6.5 \%$ & $41.2 \%$ & $8.2 \%$ & $0.0 \%$ & $8.4 \%$ & $3.6 \%$ & $52.6 \%$ & $14.3 \%$ \\
\hline \multirow{3}{*}{ 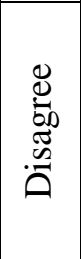 } & Count & 2 & 0 & 8 & 6 & 7 & 2 & 0 & 0 & 25 \\
\hline & $\%$ in total & $8.0 \%$ & $0.0 \%$ & $32.0 \%$ & $\begin{array}{c}24.0 \\
\%\end{array}$ & $28.0 \%$ & $8.0 \%$ & $0.0 \%$ & $0.0 \%$ & $100.0 \%$ \\
\hline & $\begin{array}{c}\% \text { within } \\
\text { VDC }\end{array}$ & $4.7 \%$ & $0.0 \%$ & $15.7 \%$ & $\begin{array}{c}12.2 \\
\%\end{array}$ & $15.6 \%$ & $2.4 \%$ & $0.0 \%$ & $0.0 \%$ & $6.3 \%$ \\
\hline \multirow{3}{*}{ 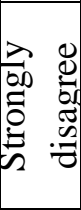 } & Count & 5 & 0 & 2 & 1 & 3 & 0 & 0 & 0 & 11 \\
\hline & $\%$ in total & $45.5 \%$ & $0.0 \%$ & $18.2 \%$ & $9.1 \%$ & $27.3 \%$ & $0.0 \%$ & $0.0 \%$ & $0.0 \%$ & $100.0 \%$ \\
\hline & $\begin{array}{c}\% \text { within } \\
\text { VDC }\end{array}$ & $11.6 \%$ & $0.0 \%$ & $3.9 \%$ & $2.0 \%$ & $6.7 \%$ & $0.0 \%$ & $0.0 \%$ & $0.0 \%$ & $2.8 \%$ \\
\hline \multirow{3}{*}{ 氶 } & Count & 43 & 62 & 51 & 49 & 45 & 83 & 28 & 38 & 399 \\
\hline & $\%$ in total & $10.8 \%$ & $15.5 \%$ & $12.8 \%$ & $\begin{array}{c}12.3 \\
\% \\
\end{array}$ & $11.3 \%$ & $20.8 \%$ & $7.0 \%$ & $9.5 \%$ & $100.0 \%$ \\
\hline & $\begin{array}{c}\% \text { within } \\
\text { VDC }\end{array}$ & $100 \%$ & $100 \%$ & $100 \%$ & $100 \%$ & $100 \%$ & $100 \%$ & $100 \%$ & $100.0 \%$ & $100.0 \%$ \\
\hline \multicolumn{11}{|c|}{ Chi-Square Tests } \\
\hline \multirow{2}{*}{\multicolumn{4}{|c|}{ Pearson Chi-Sauare }} & \multicolumn{2}{|c|}{ Value } & & df & \multicolumn{3}{|c|}{ Asymp. Sig. (2-sided) } \\
\hline & & & & \multicolumn{2}{|c|}{$201.683^{\mathrm{a}}$} & & 28 & \multicolumn{3}{|c|}{.000} \\
\hline
\end{tabular}

Source: Field Survey, 2014

The statistical analysis of Pearson Chi-square test found that there was significant association $(\mathrm{P}=.000)$ between the types of VDCs and contribution of MWSP in road construction at $95 \%$ confidence interval.

\section{Contribution of Melamchi Water Supply Project in off-seasonal vegetable farming}

Vegetable farming is one of the regular sources of income also so now a day, most of the program has incorporated the skill based training or orientation to promote the agricultural and other small scale business.

The data of table no. 5 showed that in total only $1.5 \%$ strongly agreed followed by 23.2\% agreed that MWSP had contributed in the field of off-seasonal vegetable farming. 34.8\% respondents gave the neutral answer and rest $40.4 \%$ respondents were disagreed in the same statement. In comparison of VDCs, $15.9 \%$ of Helambu, $21.6 \%$ of Ichok, $28.5 \%$ of Kiula, $17.8 \%$ of Mahankal, $48.2 \%$ of Melamchi, $17.9 \%$ of Palchok and $28.9 \%$ of Talamaranga reported that they agreed in the contribution of MWSP in off-seasonal vegetable farming. Respondent of Duwachaur was not agreed in contribution of MWSP in off-seasonal vegetable farming. 
ISSN: 2362-1303 (Paper) | eISSN: 2362-1311(Online)

JOURNAL OF ADVANCED ACADEMIC RESEARCH (JAAR) July 2015

Table 5: Contribution of Melamchi Water Supply Project in off-seasonal vegetable farming

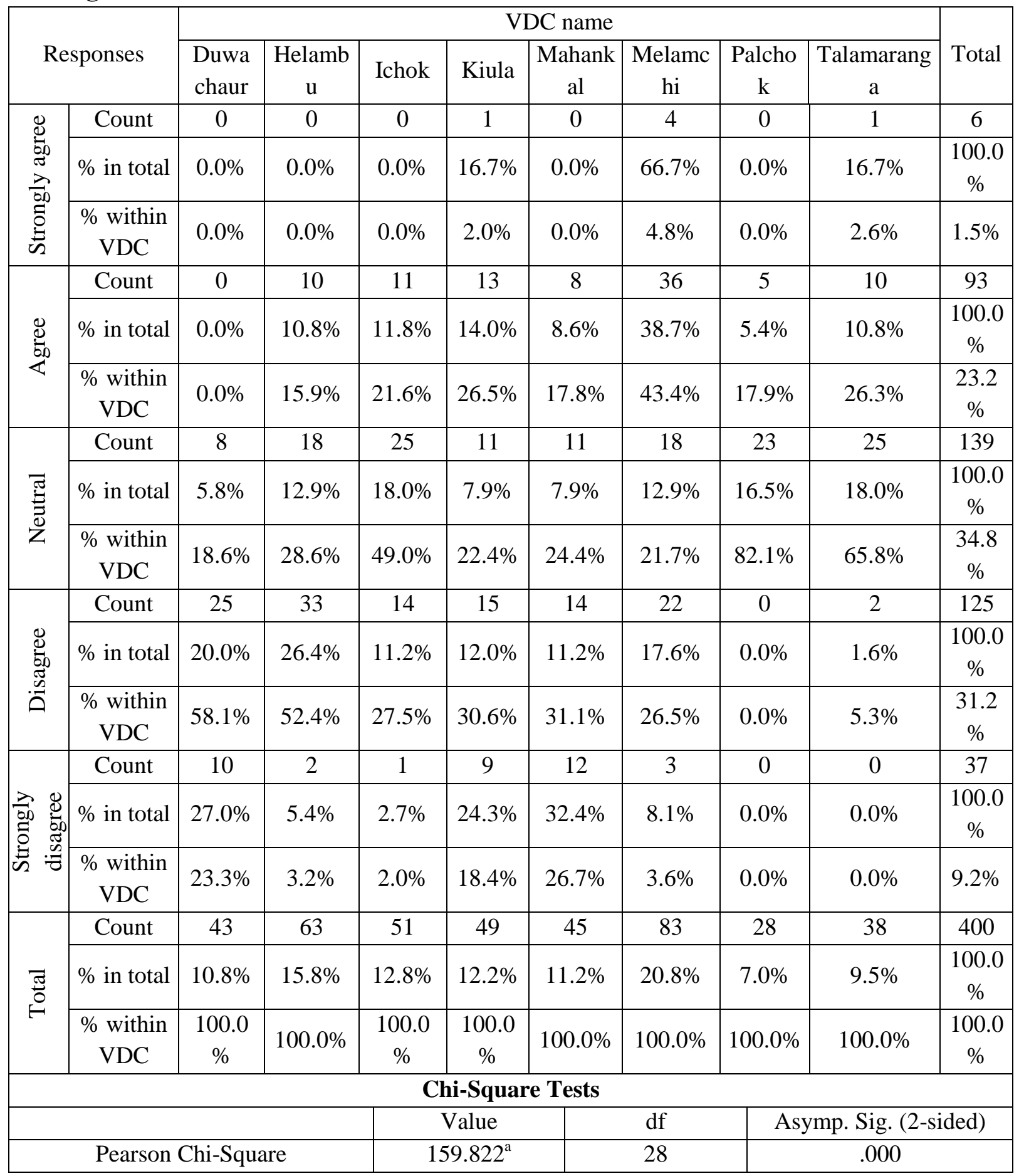

Source: Field Survey, 2014 
ISSN: 2362-1303 (Paper) | eISSN: 2362-1311(Online)

JOURNAL OF ADVANCED ACADEMIC RESEARCH (JAAR)

July 2015

The statistical analysis of Pearson Chi-square test found that there was significant association $(\mathrm{P}=.000)$ between the types of VDCs and contribution of MWSP in off-seasonal vegetable farming at $95 \%$ confidence interval.

The community people were trained in off-seasonal vegetable farming under the Income Generation/Community Development program. The program was providing guidance and funding to promote income generation and community development activities through capacity building at the local level, under the pre-existing Local Governance Program (LGP), includes formation of COs and CMCs, seed grant capital, to form savings and credit groups, agriculture and livestock development programs etc (Melamchi Water Supply Project, 2015).

\section{CONCLUSION}

The concluding remarks of the study show that the Melamchi Water Supply Project is one Mega Project of Government of Nepal implementing with the support of Asian Development Bank (ADB). Because of the political fluctuation of country, the project's activities are affected so work progress is not as much as expected by the community people. Project had adopted the public participation approach to make the program more effective. The project has two subprojects: Melamchi River Water Diversion Subproject (Subproject -1) and Kathmandu Valley Water Supply and Sanitation Subproject (Subproject -2). Specifically, the project is doing technical work; doing construction work of preparing the tunnel and water treatment plant and community development program. Under the social development program, it was doing the health, education, rural electrification, income generating activities etc. to improve the quality of life of community people. The study found that the community people were happy from the MWSP's support. The contribution of MWSP was significantly different between the VDCs. The survey data showed that around 30\% respondent agreed that MWSP had supported in water supply for agriculture where very less numbers of people of Duwachaur, Helambu Ichowak agreed. Comparatively, MWSP contribution was significantly high in road construction followed by support in education. The study found the need of further study to explore the challenges of MWSP to make the program effective and extend in other remote areas of district.

\section{REFERENCES}

Central Bureau of Statistics. (2011). Agricultural Census 2011. National Planning Commission Secretariat. Kathmandu, Nepal: Government of Nepal.

Melamchi Drinking Water Development Committee. (April 2014). Report of Melamchi Water Supply Project. Kathmandu: Melamchi Water Supply Project. 
ISSN: 2362-1303 (Paper) | eISSN: 2362-1311(Online)

JOURNAL OF ADVANCED ACADEMIC RESEARCH (JAAR) July 2015

Melamchi Water Supply Project. (2015). Home: Melamchi Water Supply Project. Retrieved September 4, 2015, from Melamchi Water Supply Project: http://www.melamchiwater.org/home/melamchi-ws-project.php

Pokharel, B. (26-30 June, 2006). The Politics of Partnership Program: A Case Study from Income Generation and Community Development Programme of MWSP . 19th European Conference on Modern South Asian Studies Panel 'Local Democracy in South Asia, (p. 14). Lieden; the Netherlands .

Rajaona, A. M., Sutterer, N., \& Asch, F. (2012, December 4). Potential of Waste Water Use for Jatropha Cultivation in Arid Environments. Agriculture - Open Access Journal, 2, 376-392.

Ssali, M. J. (2015, April 1). Magazines: Monitor Publications Ltd. Retrieved September 4, 2015, from Monitor Publications Ltd: http://www.monitor.co.ug/Magazines/Farming/The-importance-of-water-in-farming//689860/2671384/-/dsculsz/-/index.html

The World Bank Group. (2014). A Vision for Nepal: Policy Notes for the Government. Nepal: The World Bank Group.

TRADING ECONOMICS. (2015). Retrieved September 5, 2015, from TRADING ECONOMICS: http://www.tradingeconomics.com/nepal/gdp-per-capita

Water Encyclopedia. (2015). Retrieved September 4, 2015, from Advameg, Inc.: http://www.waterencyclopedia.com/A-Bi/Agriculture-and-Water.html 